\title{
Cytogenetic and Evolutionary Relationships in the Genus Axonopus (Gramineae)
}

\author{
M. Clara M. Hickenbick ${ }^{1}$, J.F. M. Valls, F. M. Salzano \\ and $M$. Irene $B$. de Moraes Fernandes \\ Departamentos de Genética e Botânica, Instituto de Biociências, \\ Universidade Federal do Rio Grande do Sul, \\ Porto Alegre, RS, Brazil
}

Received July 6, 1973

The genus Axonopus includes at present some 110 species and 30 varieties distributed mainly in the tropical and subtropical regions of the Americas, from Southern United States to Northern Argentina. A large number of species occur in Brazil, and the genus may have originated in the central portion of this country or neighboring places. Cytological investigations in this grass were made by Burton (1942), Janaki-Ammal (1945), Brown (1948, 1950), Delay (1950), Nuñes (1952), de Wet and Anderson (1956), Markus (1960), Gledhill (1962, 1966), Reeder (1966), Gould and Soderstrom (1967, 1970), Gould (1968), Pohl and Davidse (1971), and Davidse and Pohl (1972). However, with the exception of the papers of Gledhill $(1962,1966)$ and Davidse and Pohl $(1972)$ who reported meiotic studies, all the others were restricted to the determination of chromosome numbers, investigated as only one aspect of the taxonomic analysis of the species of a given region. The present communication reports cytogenetic, ecologic and morphologic data from the native and cultivated species as well as natural hybrids present in the State of Rio Grande do Sul, other Brazilian States, and Uruguay. Taking these results into consideration, hypotheses concerning the possible origin and evolution of these forms were formulated.

\section{Material and methods}

The plants studied are listed in Table 1, where there are also indications about their place of origin. All of them were cultivated at the Agronomic Center of the Federal University of Rio Grande do Sul or at the greenhouse of the State's Department of Agriculture.

Specimens from the strains studied were prepared and deposited at the herbarium either of the Diretoria da Produção Animal da Secretaria de Agricultura do Estado do Rio Grande do Sul (which is coded by the letters BLA) or of the Departamento de Botanica, Instituto de Biociências in Porto Alegre (ICN). The numbers under which they were filed are the same as those indicated in Table 1.

In relation to the series Suffulti the taxonomy of the native forms from Rio Grande do Sul is in a state of flux, no agreement existing among Parodi (1938),

1 Née Mallmann 


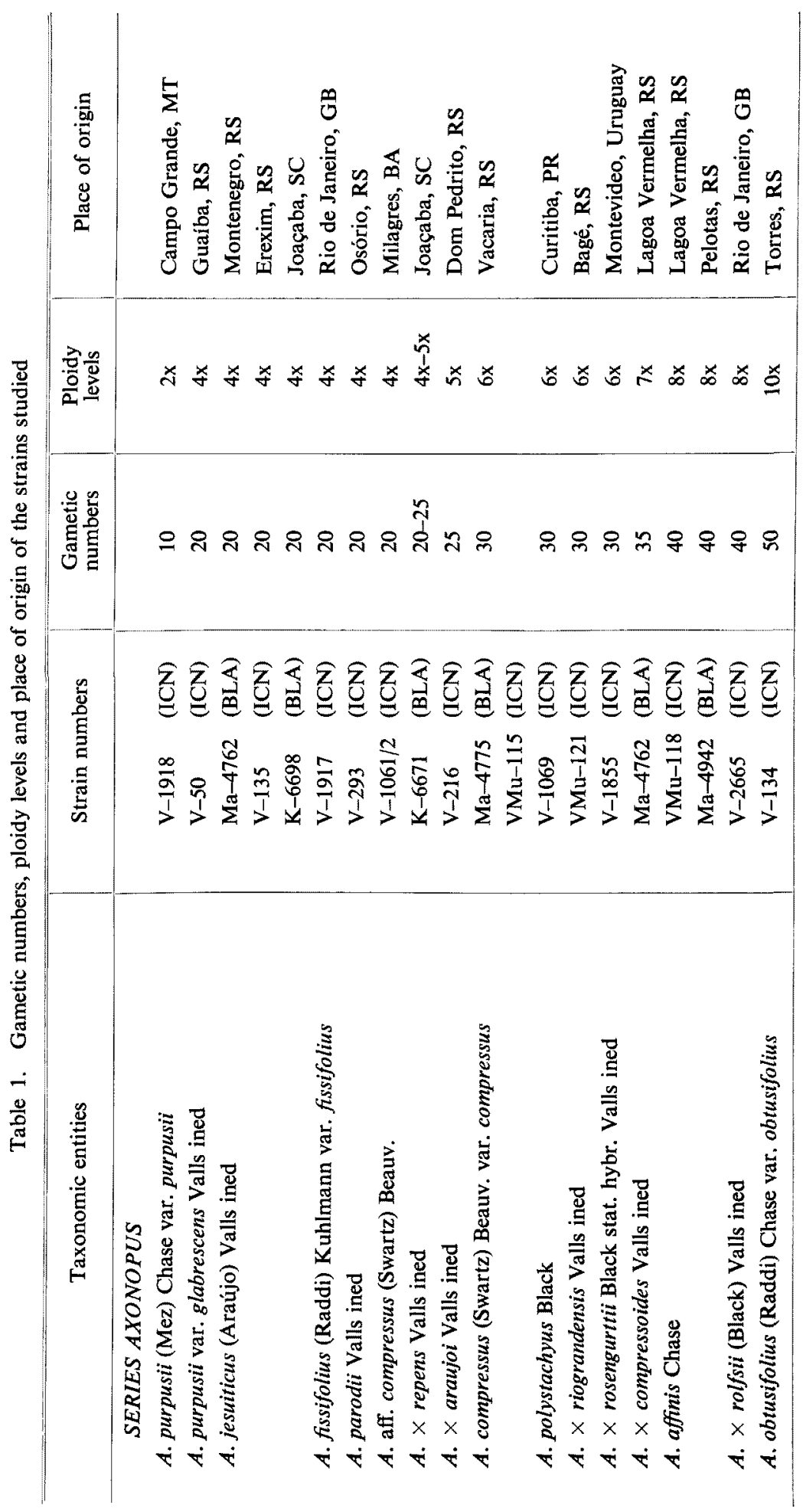




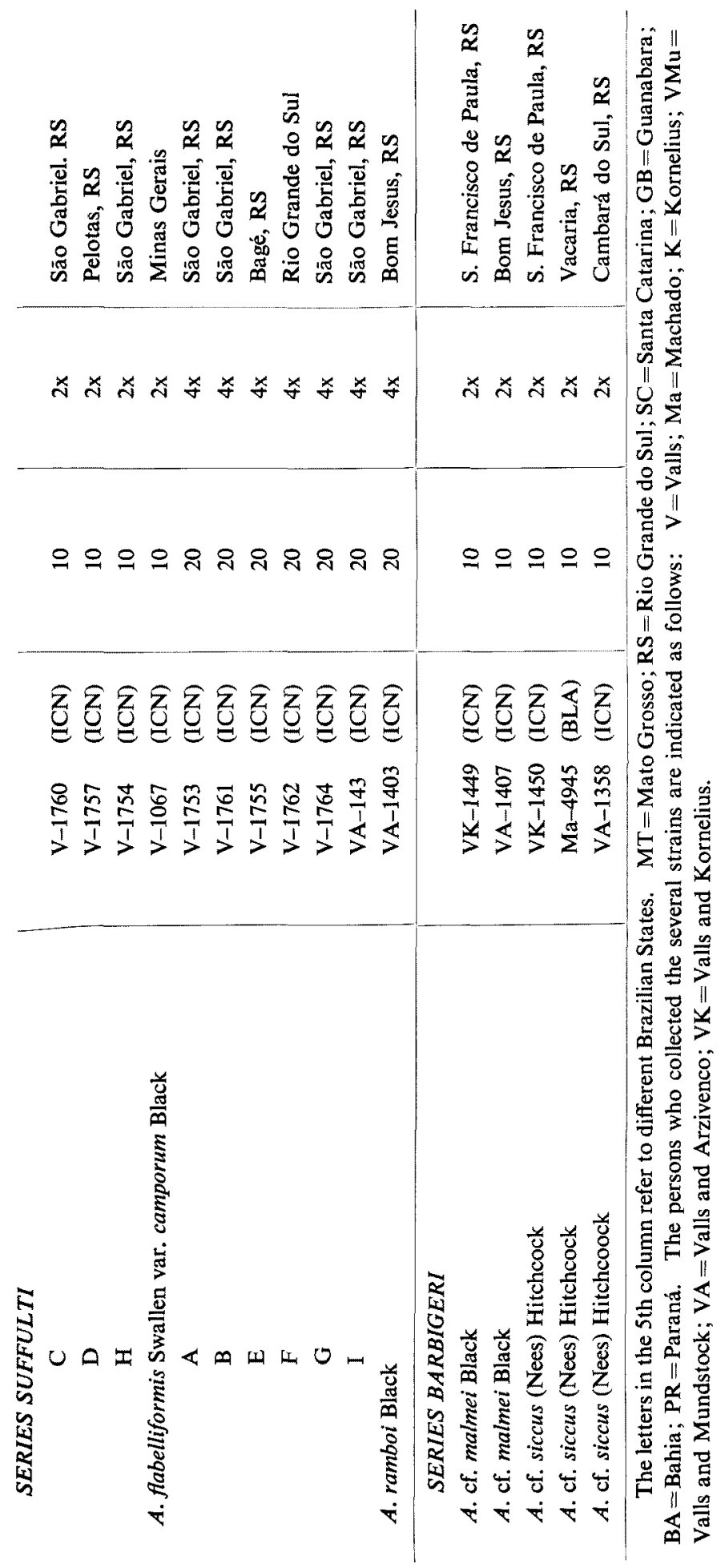




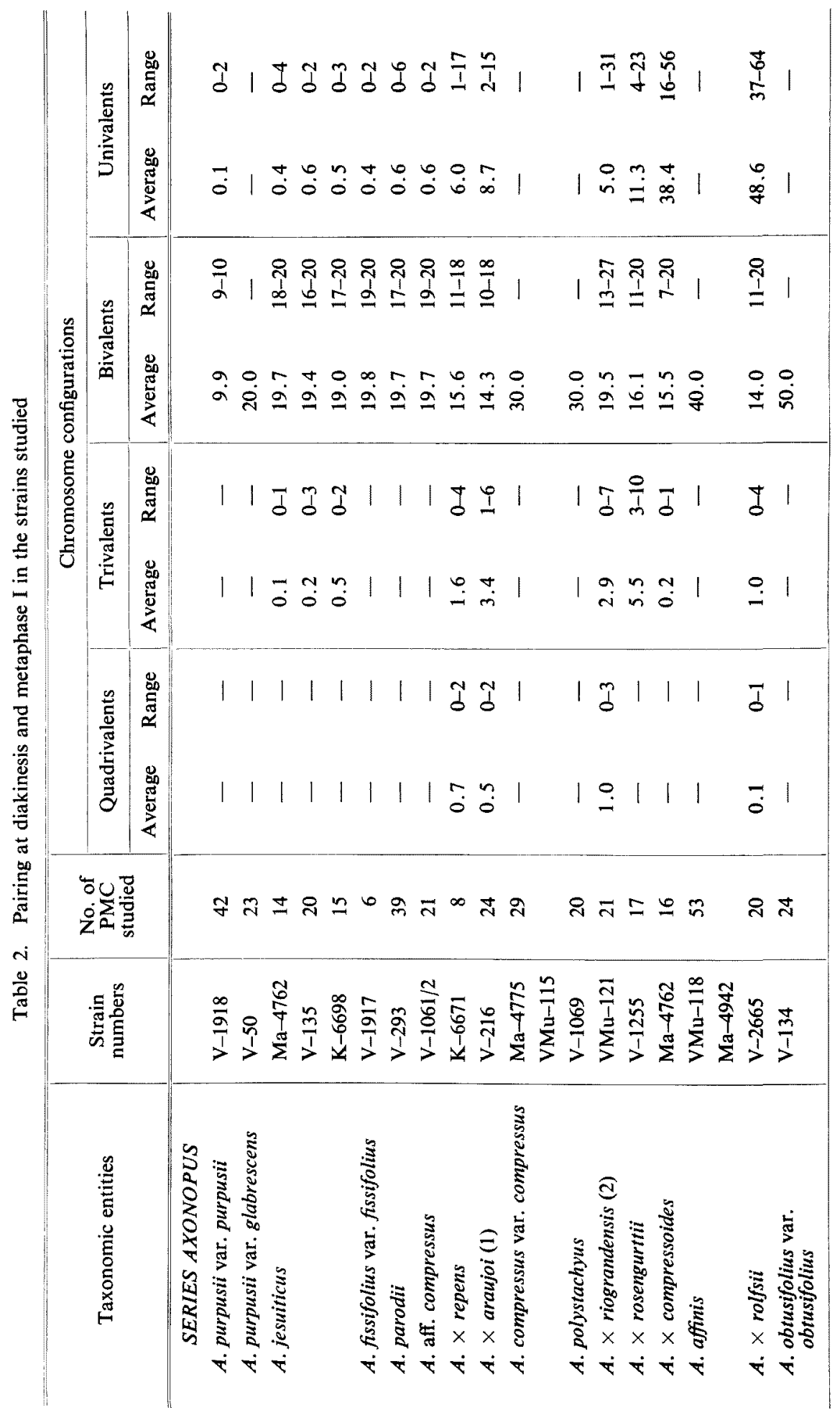




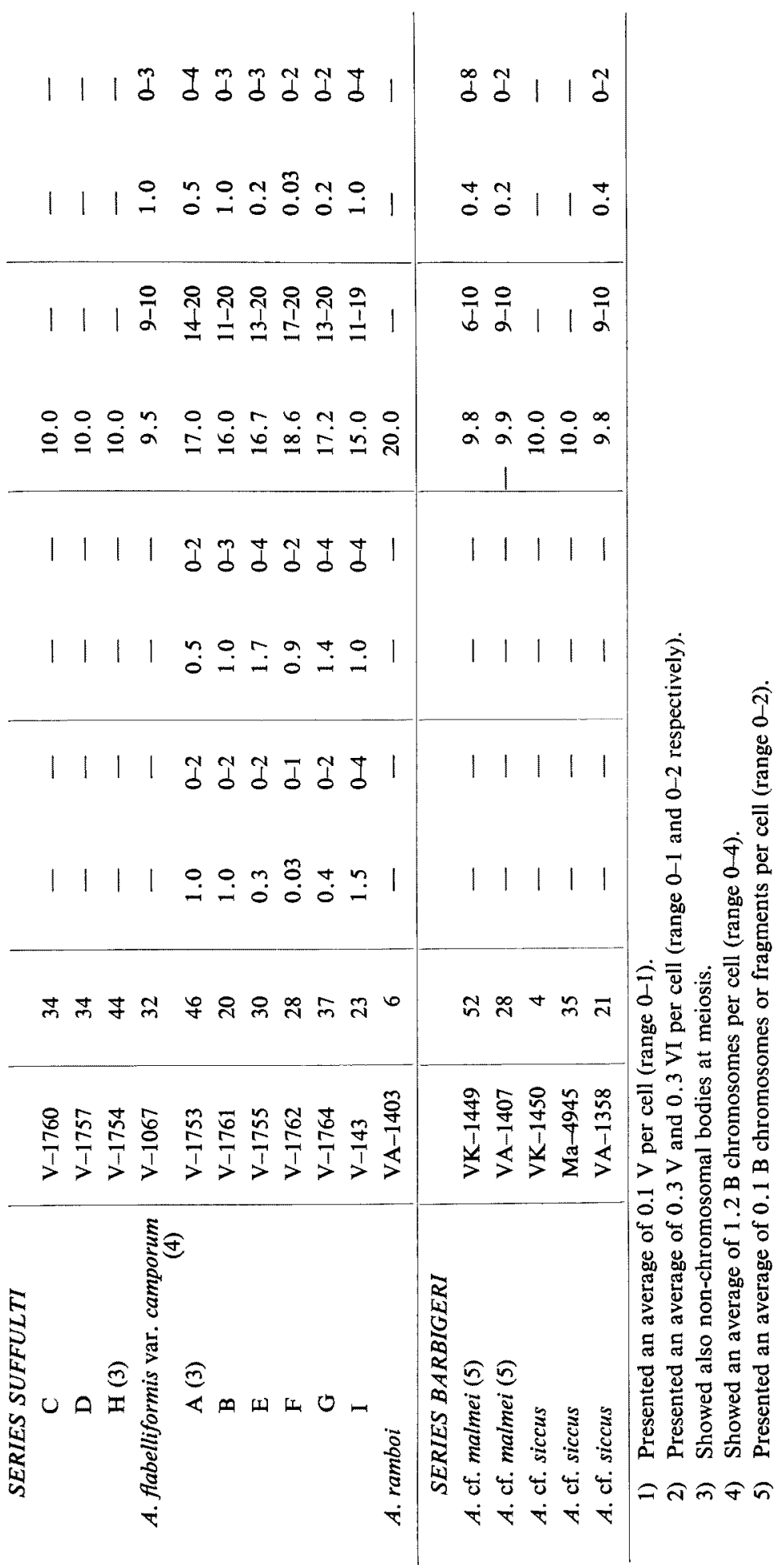




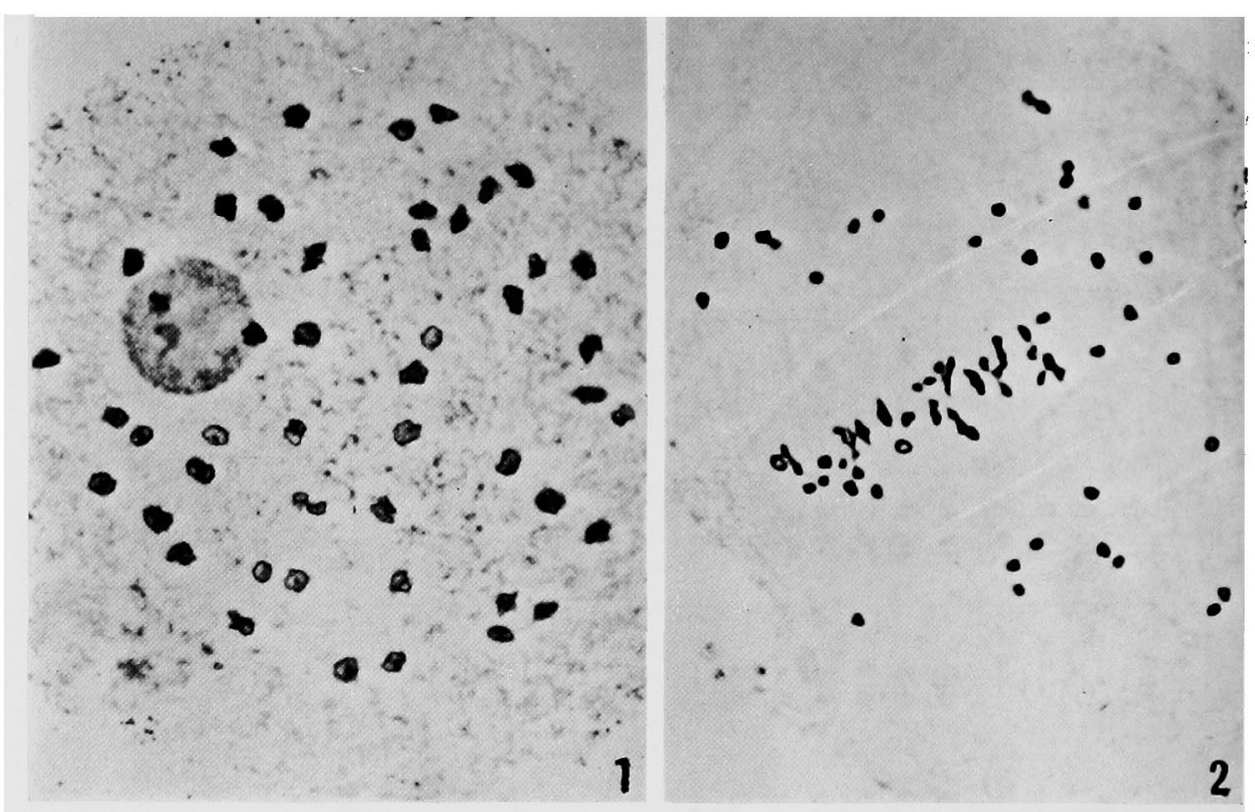

Figs. 1-2. 1, diakinesis in A. obtusifolius var. obtusifolius showing 50 II. 2, metaphase I in $A$. $\times$ rolfsii with 4 III, 10 II and 48 I.

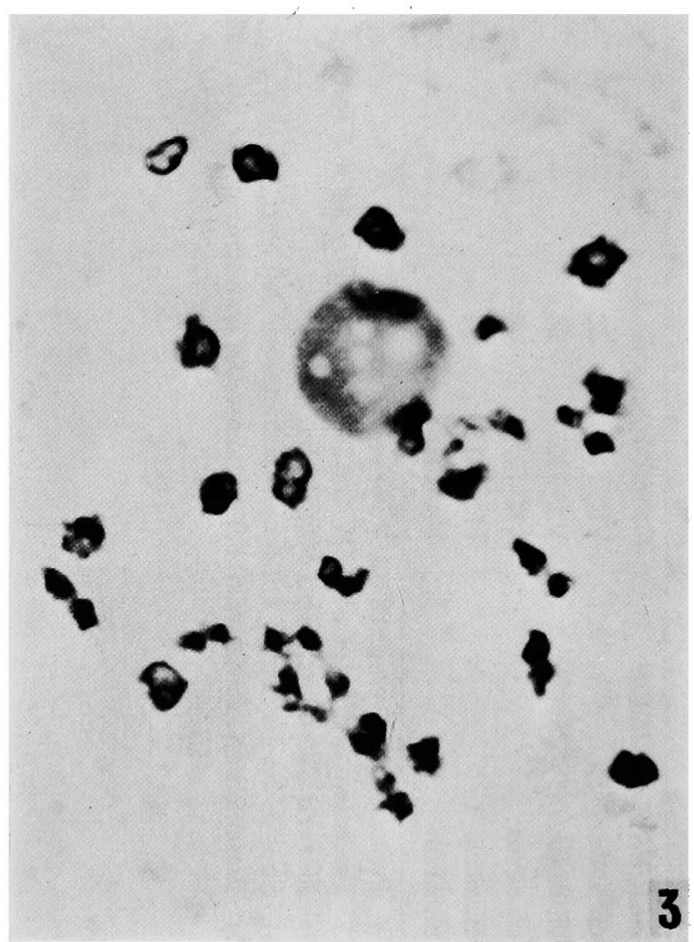

Fig. 3. Diakinesis in $A$. $\times$ riograndensis with $1 \mathrm{~V}, 2 \mathrm{III}, 24 \mathrm{II}$ and $1 \mathrm{I}$.
Black (1963) and Rosengurtt et al. (1970) as to what characteristics should be used for their differentiation. Therefore we decided to consider the whole series as one complex in which morphologically distinct forms were identified by letters, without an immediate concern with Latin names.

For the meiotic studies the inflorescences were fixed and stored in Newcomer's (1953) fluid, modified by the substitution of propionic for acetic acid. The pollen mother cells were stained with propionic carmine and the slides made permanent by the dry ice method. Pollen sterility was determined by the stainability of the pollen with aceto-carmine. 


\section{Results}

The gametic numbers and ploidy levels of the taxa studied are presented in Table 1. They varied from 10 to $50(2 \mathrm{x}-10 \mathrm{x})$ in the series Axonopus; the series Suffulti shows diploid and tetraploid entities, while in Barbigeri only diploids were observed. The number of cells studied is shown in Tables 2 and 3.

Table 2 furnishes information on the pairing at diakinesis and metaphase $I$ in the strains studied. In the series Axonopus an essentially regular behavior was observed in the diploid $A$. purpusii var. purpusii, in four of the five tetraploid forms, in the hexaploids $A$. compressus var. compressus and $A$. polystachyus, as well as in A. affinis $(8 \mathrm{x})$ and $A$. obtusifolius var. obtusifolius $(10 \mathrm{x}$; Fig. 1). A low frequency of trivalents was found in the three strains of $A$. jesuiticus, while in the remaining

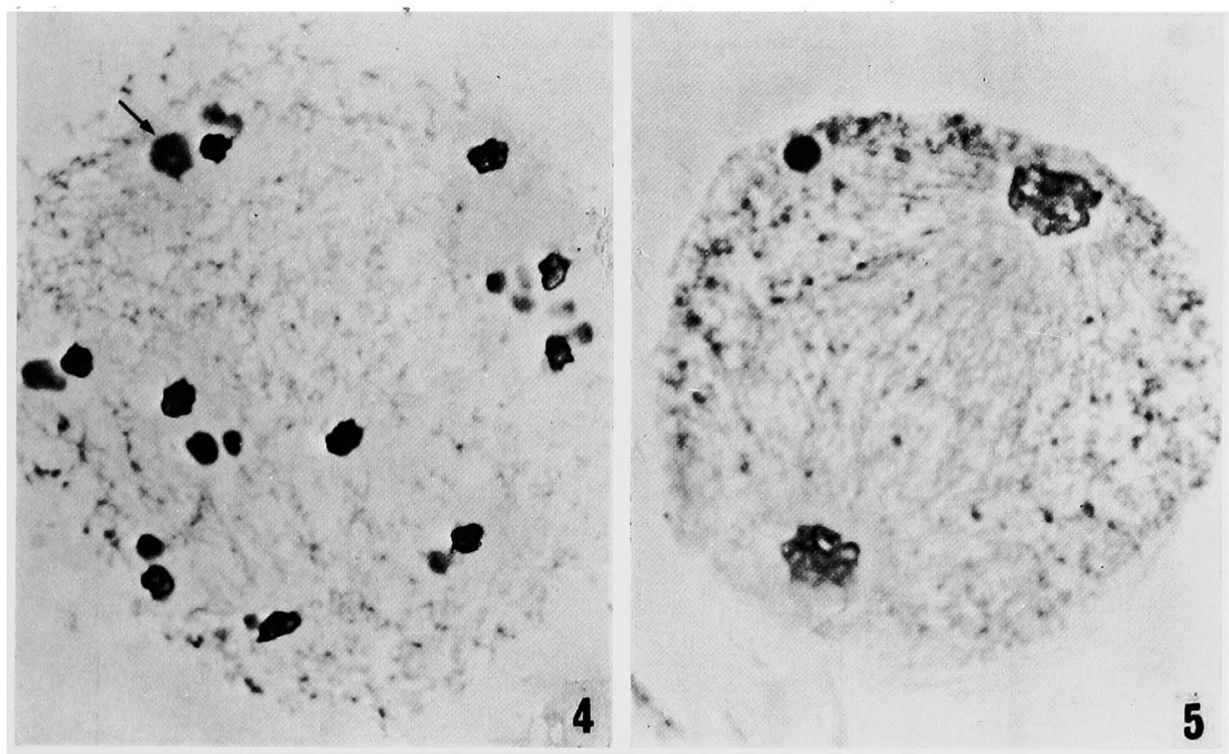

Figs. 4-5. 4, diakinesis in strain Valls 1754 of the Suffulti series showing round bodies near the bivalents. 5, telophase I in strain Valls 1753 of the Suffulti series showing a nuclear body.

six entities a highly irregular pattern was seen, with the occurrence of uni, tri, quadri, penta and hexavalents (see, for instance, Figs. 2 and 3).

In the series Suffulti (Table 2) the diploids also showed a quite regular pairing; however an average of $1.2 \mathrm{~B}$ chromosomes per cell were found in A. flabelliformis var. camporum. With the exception of $A$. ramboi all the other tetraploids presented irregular behavior with the occurrence of multiple associations. As for the Barbigeri series, the forms studied showed what was considered to be an essentially regular pattern but in $A$. cf. malmei B chromosomes or fragments were present.

Peculiar non-chromosomic bodies were observed in two strains of the series Suffulti. In three of the 44 cells studied in diakinesis and metaphase I of strain Valls 1754 we have encountered structures which resemble what Walters (1968) described as round bodies in Zea mays (Fig. 4). She believes that the latter may 


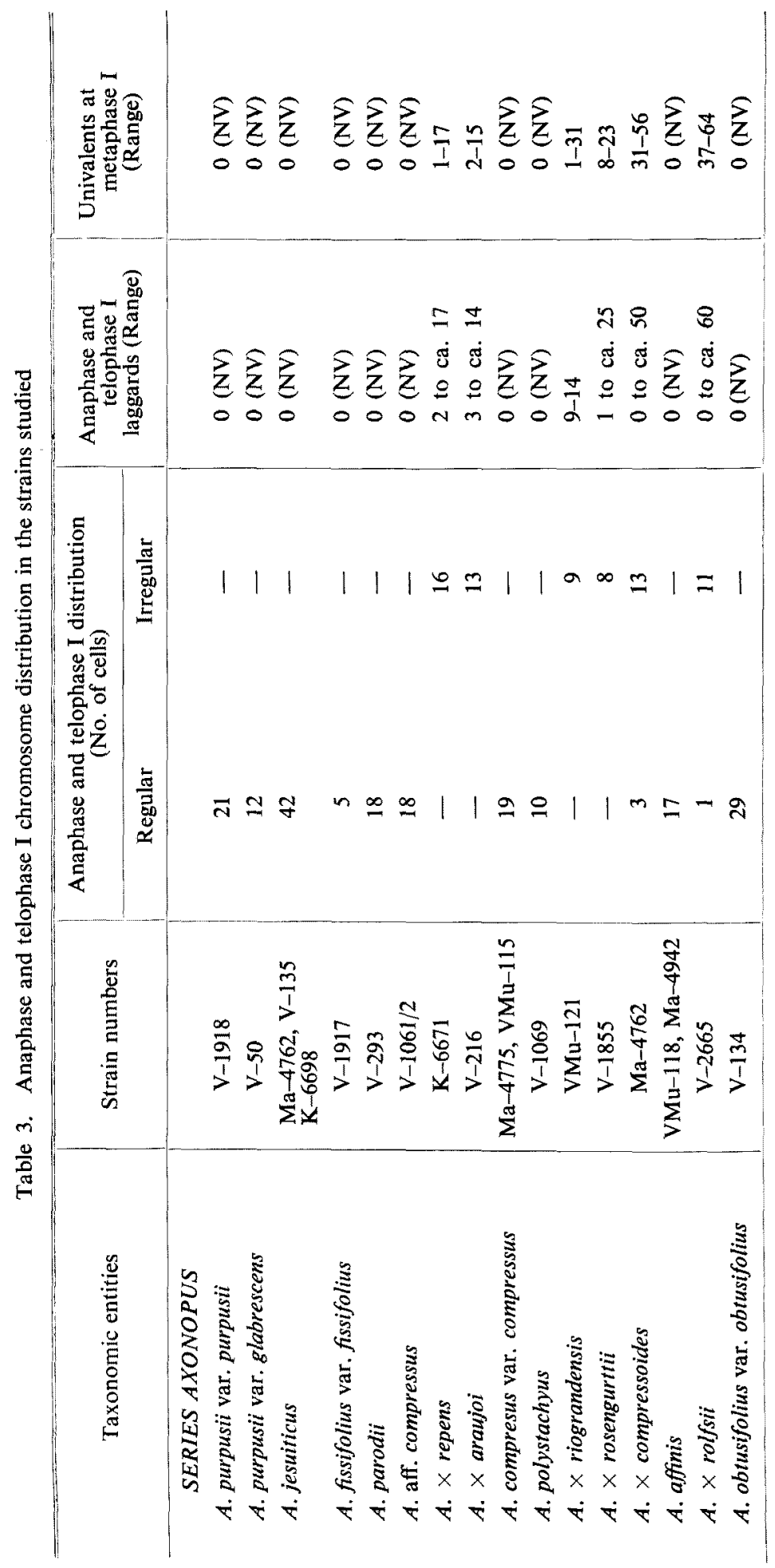




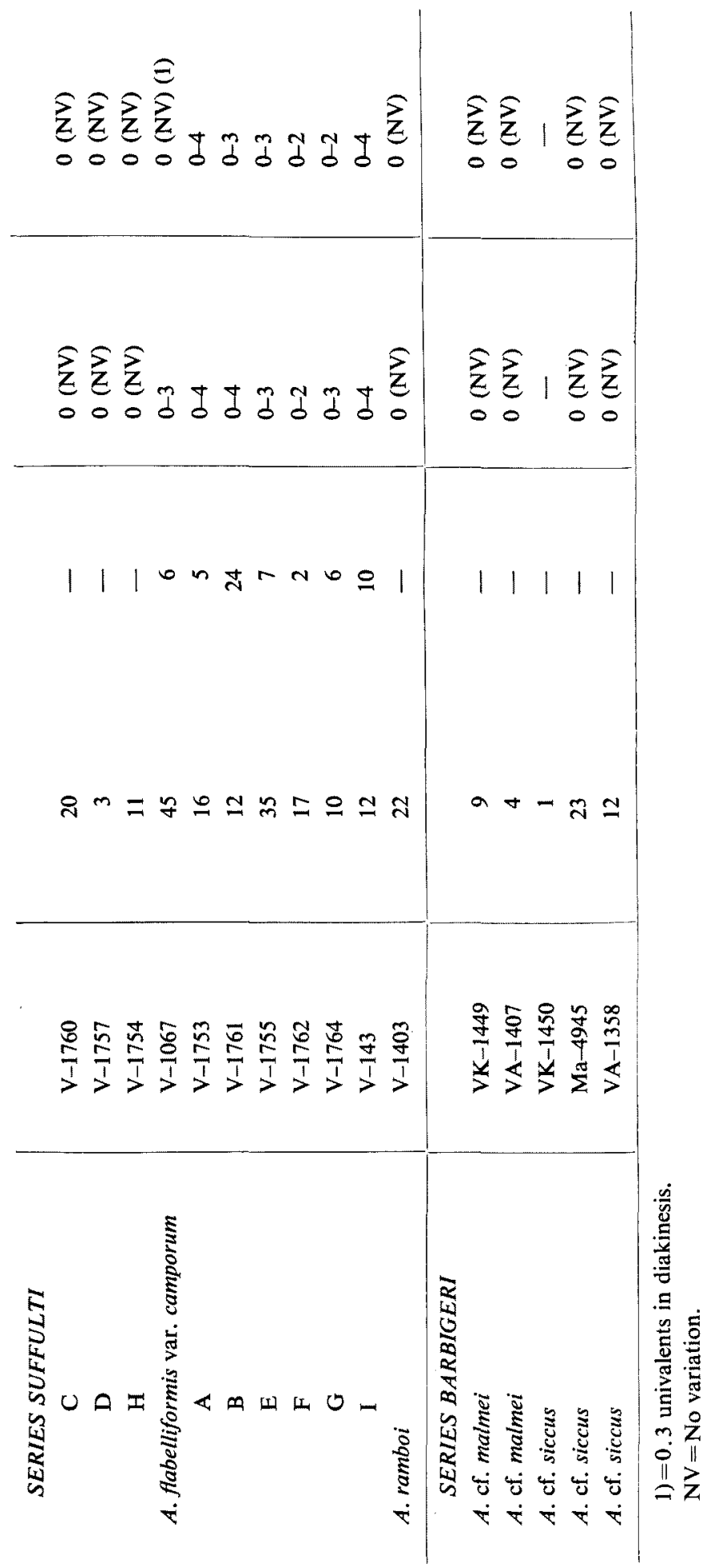




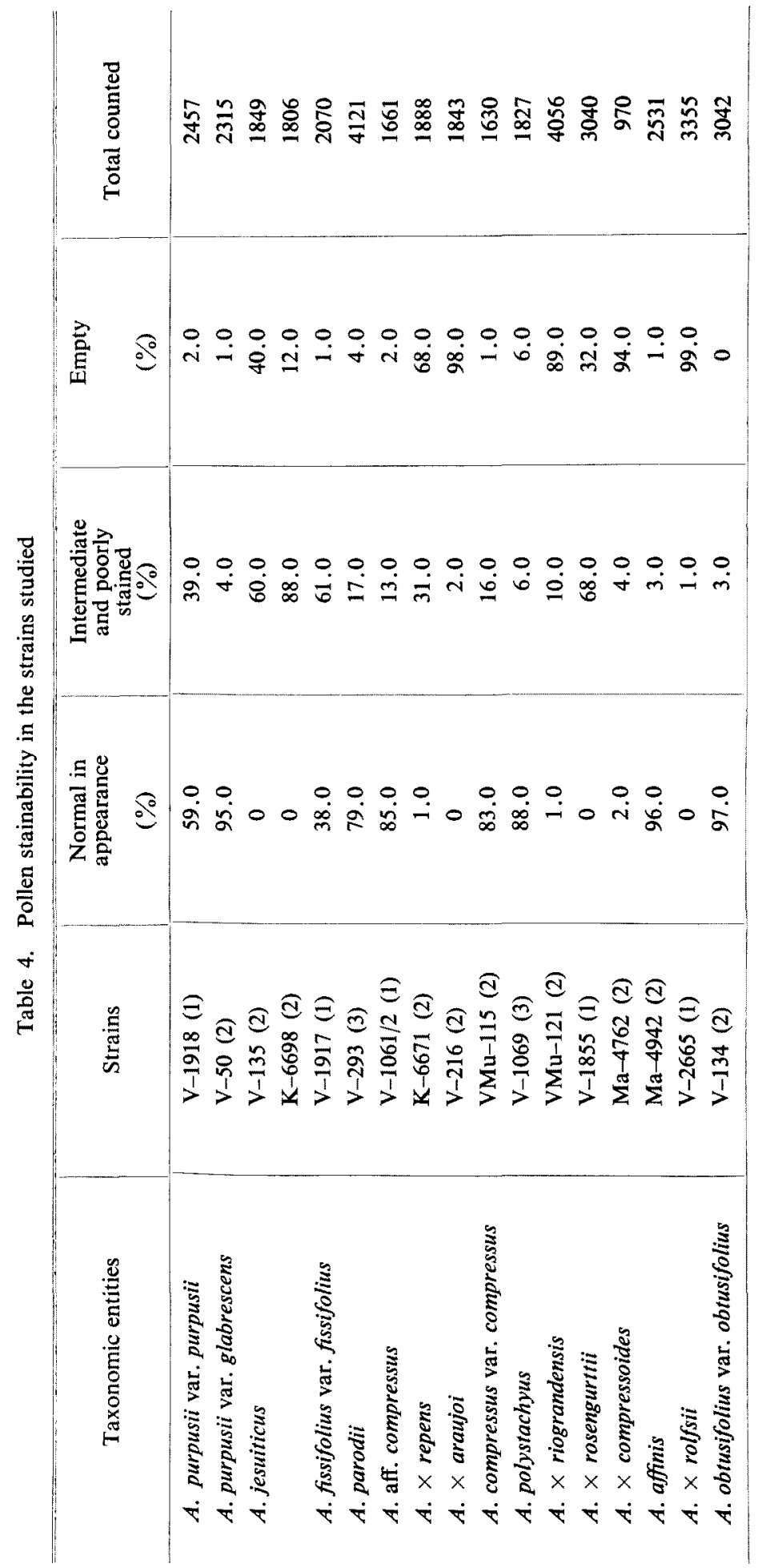




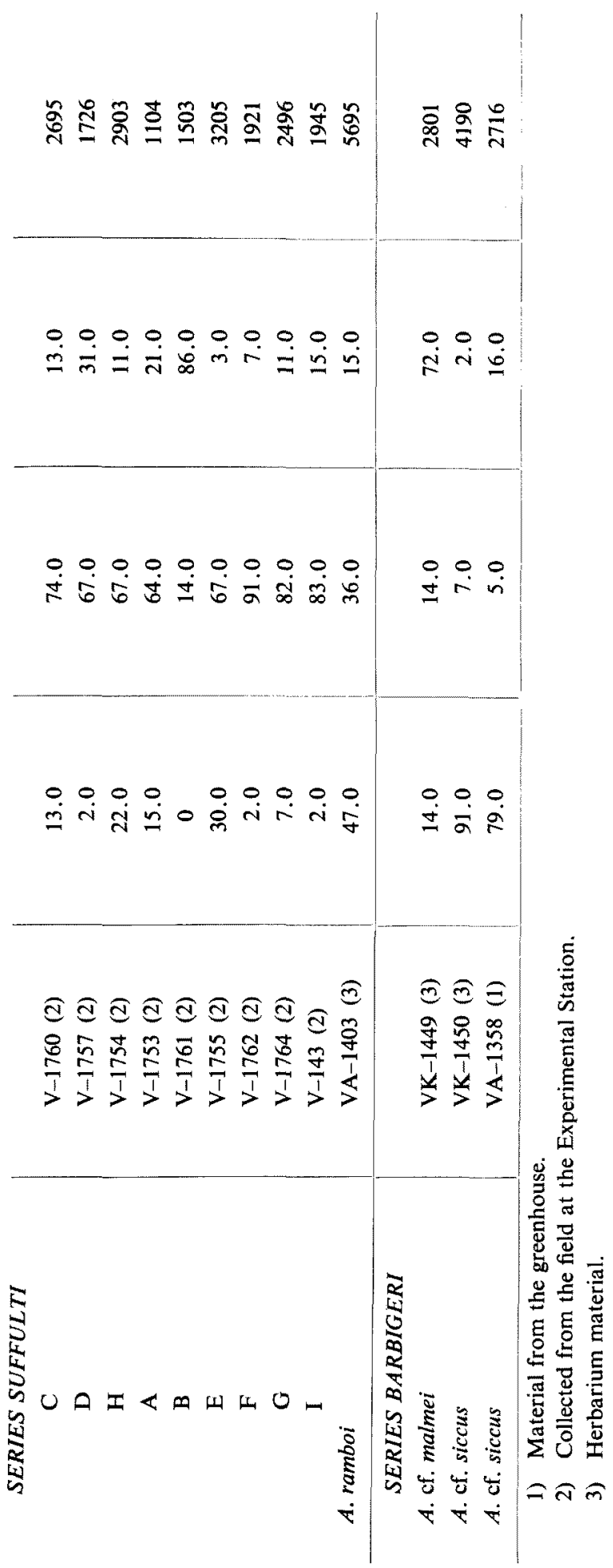




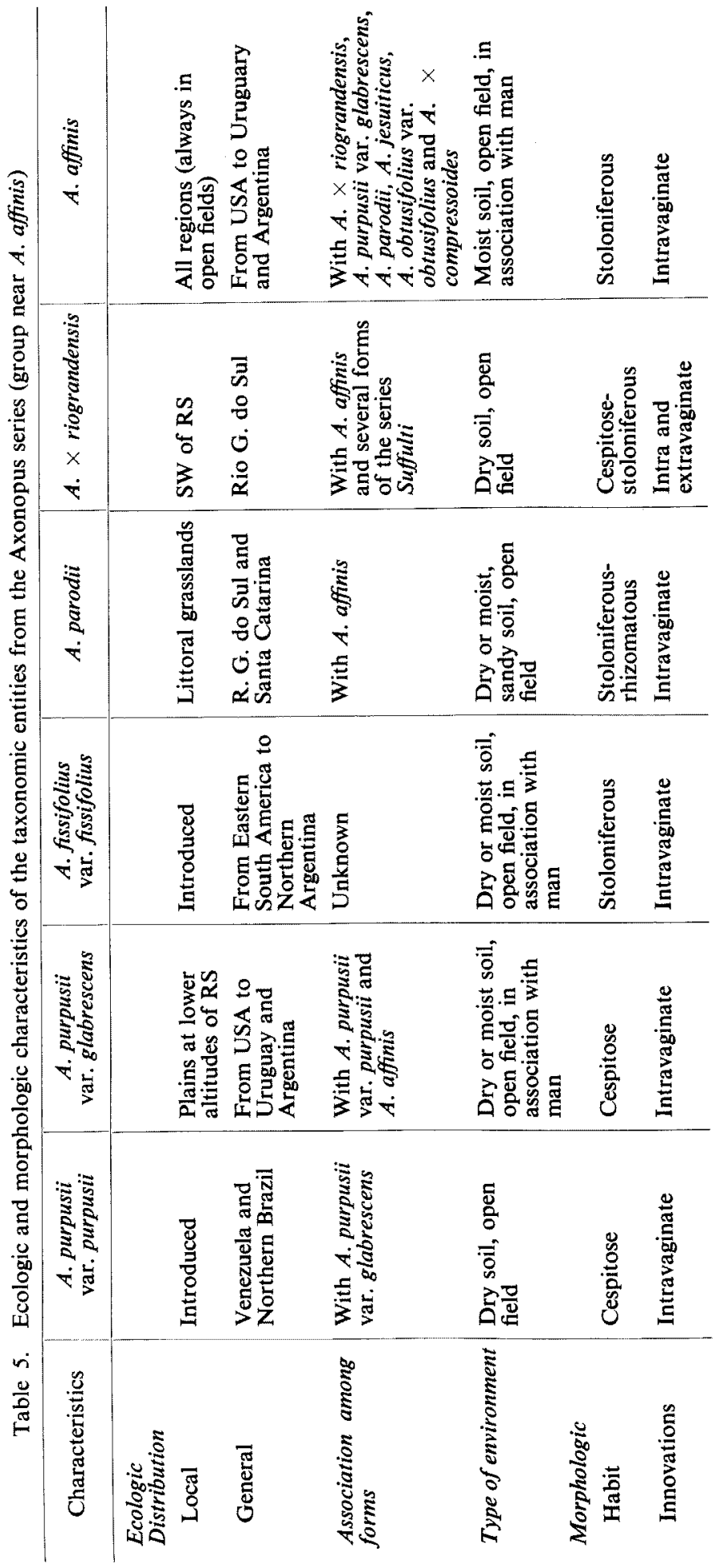




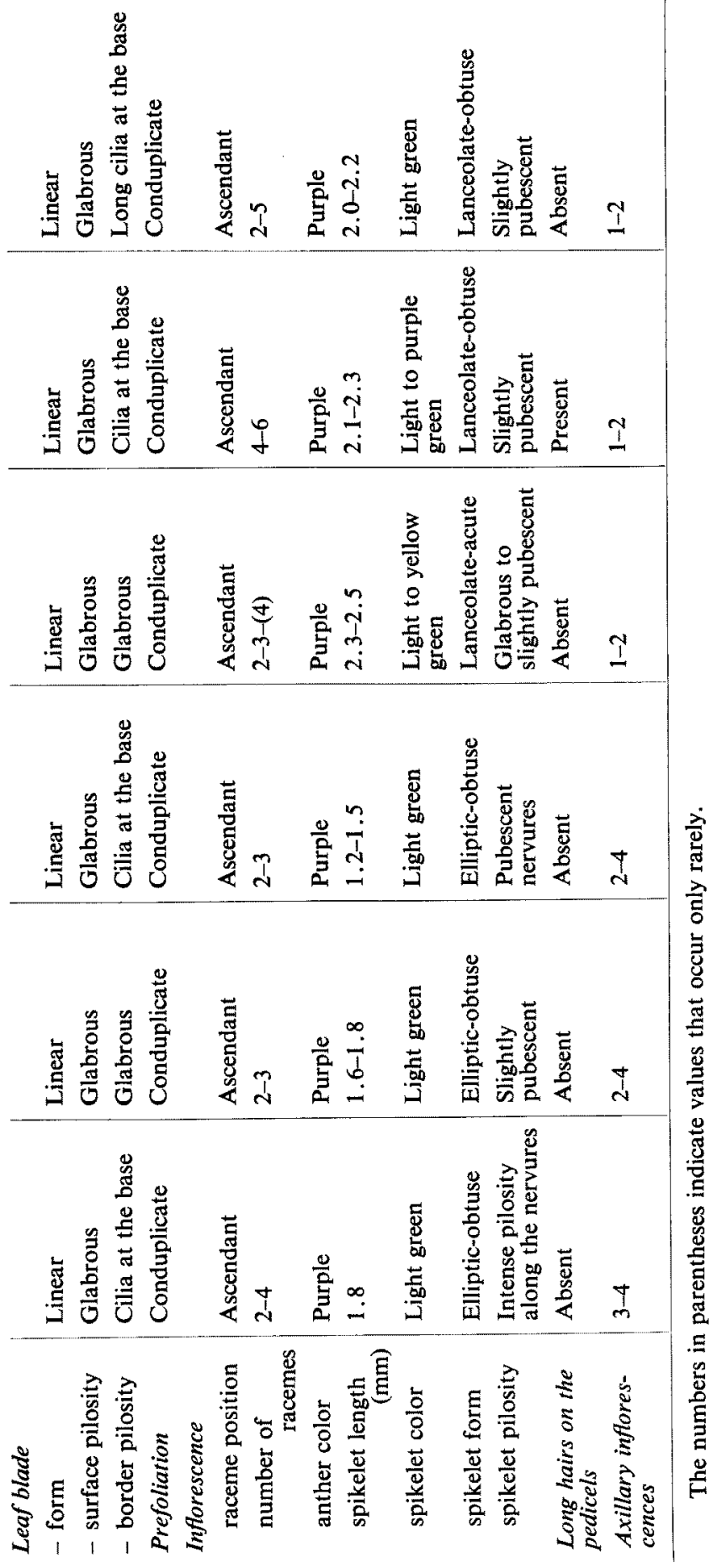


Table 6. Ecologic and morphologic characteristics of the taxonomic entities from

\begin{tabular}{|c|c|c|c|c|}
\hline Characteristics & A. jesuiticus & A. $\times$ repens & A. $\times$ araujoi & A. $\times \underset{\text { rosengurt }-}{\text { tii }}$ \\
\hline \multicolumn{5}{|l|}{$\begin{array}{l}\text { Ecologic } \\
\text { Distribution }\end{array}$} \\
\hline Local & $\begin{array}{l}\text { Plains, Uruguay } \\
\text { river }\end{array}$ & Introduced & $\begin{array}{l}\text { Probably } \\
\text { introduced }\end{array}$ & Introduced \\
\hline General & $\begin{array}{l}\text { Brazil and Argen- } \\
\text { tina }\end{array}$ & $\begin{array}{l}\text { Paraná, Santa } \\
\text { Catarina, RS }\end{array}$ & $\begin{array}{l}\text { RS (known only } \\
\text { in cultivation) }\end{array}$ & $\begin{array}{l}\text { Uruguay and } \\
\text { Argentina }\end{array}$ \\
\hline $\begin{array}{l}\text { Association } \\
\text { among entities }\end{array}$ & $\begin{array}{l}\text { With } A . \text { affinis } \\
\text { and } A . \times \\
\text { rosengurttii }\end{array}$ & Unknown & Unknown & $\begin{array}{l}\text { With A. jesu- } \\
\text { iticus }\end{array}$ \\
\hline $\begin{array}{l}\text { Type of } \\
\text { environment }\end{array}$ & $\begin{array}{l}\text { Moist, shady } \\
\text { areas, open field, } \\
\text { cultivated }\end{array}$ & $\begin{array}{l}\text { Shady areas, } \\
\text { cultivated }\end{array}$ & $\begin{array}{l}\text { Shady areas, } \\
\text { cultivated }\end{array}$ & $\begin{array}{l}\text { Shady areas at } \\
\text { the border of } \\
\text { woods }\end{array}$ \\
\hline \multicolumn{5}{|l|}{ Morphologic } \\
\hline Habit & Stoloniferous & Stoloniferous & Stoloniferous & Stoloniferous \\
\hline Innovations & $\begin{array}{l}\text { Intravaginate at } \\
\text { the stolons and } \\
\text { extravaginate at } \\
\text { the base }\end{array}$ & Intravaginate & Intravaginate & Intravaginate \\
\hline- form & Lanceolate-linear & $\begin{array}{l}\text { Lanceolate- } \\
\text { linear }\end{array}$ & Lanceolate-linear & $\begin{array}{l}\text { Lanceoolate- } \\
\text { linear }\end{array}$ \\
\hline 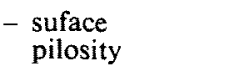 & Glabrous & Pubescent & Glabrous & Glabrous \\
\hline $\begin{array}{l}\text { - border } \\
\text { pilosity }\end{array}$ & Glabrous & Ciliate & $\begin{array}{l}\text { Sparsely } \\
\text { ciliate }\end{array}$ & Glabrous \\
\hline Prefoliation & Convolute & Convolute & Convolute & Convolute \\
\hline \multicolumn{5}{|l|}{ Inflorescence } \\
\hline raceme position & Erect & Erect & Ascendant-erect & Erect \\
\hline $\begin{array}{l}\text { number of } \\
\text { racemes }\end{array}$ & $(2)-4-10$ & $2-3$ & $2-3$ & $2-3$ \\
\hline anther color & Purple & Purple & Purple & Purple \\
\hline $\begin{array}{l}\text { spikelet length } \\
(\mathrm{mm})\end{array}$ & $1.9-2.1$ & $2.6-3.1$ & $2.5-3.0$ & $2.7-3.1$ \\
\hline spikelet color & Light green & $\begin{array}{l}\text { Light to purple } \\
\text { green }\end{array}$ & $\begin{array}{l}\text { Light to yellow } \\
\text { green }\end{array}$ & Light green \\
\hline spikelet form & Lanceolate-obtuse & Elliptic-acute & Lanceolate-acute & $\begin{array}{l}\text { Lanceolate- } \\
\text { acute }\end{array}$ \\
\hline spikelet & Glabrous to & Slightly & Slightly & Pubescent \\
\hline pilosity & slightly pubescent & pubescent & pubescent & nervures \\
\hline $\begin{array}{l}\text { Long hairs on } \\
\text { the pedicels }\end{array}$ & Absent & Absent & Absent & Absent \\
\hline $\begin{array}{l}\text { Axillary inflo } \\
\text { rescences }\end{array}$ & (1) -2 & $1-2$ & $1-2$ & $1-2$ \\
\hline
\end{tabular}

The numbers in parentheses indicate values that occur only rarely. 
the Axonopus series (group near A. compressus var. compressus)

\begin{tabular}{|c|c|c|c|c|}
\hline A. polystachyus & $\begin{array}{c}\text { A. compressus var. } \\
\text { compressus }\end{array}$ & A. $\times$ compressoides & A. $\times$ rolfsii & $\begin{array}{l}\text { A. obtusifolius } \\
\text { var. obtusifolius }\end{array}$ \\
\hline $\begin{array}{l}\text { Mixed wood, } \mathbf{N} \\
\text { of RS }\end{array}$ & $\begin{array}{l}\text { Woody regions of } \\
\text { RS }\end{array}$ & NE of RS & Introduced & $\begin{array}{l}\text { Moist grass- } \\
\text { lands and } \\
\text { forests, } E \text { of } R S\end{array}$ \\
\hline $\begin{array}{l}\text { From Minas } \\
\text { Cerais to Rio } \\
\text { Grande do Sul }\end{array}$ & $\begin{array}{l}\text { From U. S. A. to } \\
\text { Uruguay and } \\
\text { Argentina }\end{array}$ & $\begin{array}{l}\text { R. G. do Sul, } \\
\text { Santa Catarina } \\
\text { and Paraná }\end{array}$ & $\begin{array}{l}\text { Minas Gerais } \\
\text { and Guanabara }\end{array}$ & $\begin{array}{l}\text { Central and } \\
\text { Southern Brazil }\end{array}$ \\
\hline $\begin{array}{l}\text { With A. compres- } \\
\text { sus }\end{array}$ & $\begin{array}{l}\text { With } A . \times \text { com- } \\
\text { pressoides and } A \text {. } \\
\text { polystachyus }\end{array}$ & $\begin{array}{l}\text { With } A \text {. affinis } \\
\text { and A. com- } \\
\text { pressus }\end{array}$ & $\begin{array}{l}\text { With A. obtusi- } \\
\text { folius var. obtusi- } \\
\text { folius }\end{array}$ & $\begin{array}{l}\text { With A. affinis } \\
\text { and A. } \times \\
\text { rolfsii }\end{array}$ \\
\hline $\begin{array}{l}\text { Woody, shady } \\
\text { areas }\end{array}$ & $\begin{array}{l}\text { Woody, shady } \\
\text { areas, in asso- } \\
\text { ciation with } \\
\text { man }\end{array}$ & $\begin{array}{l}\text { Woody, shady } \\
\text { areas, in asso- } \\
\text { ciation with } \\
\text { man }\end{array}$ & $\begin{array}{l}\text { Woody, shady } \\
\text { areas, sometimes } \\
\text { at border of } \\
\text { woods }\end{array}$ & $\begin{array}{l}\text { Woody, shady } \\
\text { areas, some- } \\
\text { times at border } \\
\text { of woods }\end{array}$ \\
\hline Cespitose & Stoloniferous & Stoloniferous & Stoloniferous & Stoloniferous \\
\hline Intravaginate & Intravaginate & Intravaginate & Intravaginate & Intravaginate \\
\hline Lanceolate-linear & Lanceolate-linear & Lanceolate-linear & Lanceolate-linear & $\begin{array}{l}\text { Lanceolate- } \\
\text { linear }\end{array}$ \\
\hline $\begin{array}{l}\text { Glabrous to } \\
\text { slightly pubescent }\end{array}$ & $\begin{array}{l}\text { Glabrous to } \\
\text { slightly pubescent }\end{array}$ & $\begin{array}{l}\text { Glabrous to } \\
\text { slightly pubescent }\end{array}$ & $\begin{array}{l}\text { Highly } \\
\text { pubescent }\end{array}$ & $\begin{array}{l}\text { Slightly } \\
\text { pubescent }\end{array}$ \\
\hline Ciliate & Ciliate & $\begin{array}{l}\text { Sparsely } \\
\text { ciliate }\end{array}$ & Ciliate & Ciliate \\
\hline Convolute & Convolute & Convolute & Convolute & Convolute \\
\hline Ascendant & Ascendant & Ascendant & Ascendant & Ascendant \\
\hline $5-20$ & $2-3$ & $2-3$ & $2-3$ & $2-(3)$ \\
\hline Purple & Yellow & Purple & Purple & Purple \\
\hline $2.0-2.2$ & $2.3-2.6$ & $2.5-2.6$ & $3.2-5.0$ & $4.5-6.0$ \\
\hline Light green & Light green & $\begin{array}{l}\text { Purple to } \\
\text { purple yellow }\end{array}$ & Light green & Light green \\
\hline Elliptic-acute & Lanceolate-acute & Lanceolate-acute & Lanceolate-acute & $\begin{array}{l}\text { Lanceolate- } \\
\text { acute }\end{array}$ \\
\hline Slightly & Pubescent & Slightly & Pubescent lateral & $\begin{array}{l}\text { Pubescent } \\
\text { lateral }\end{array}$ \\
\hline pubescent & nervures & pubescent & nervures and rachis & nervures \\
\hline Absent & Absent & Absent & Absent & Absent \\
\hline $1-2$ & (1) -2 & $2-5$ & $1-(2)$ & $1-2$ \\
\hline
\end{tabular}


result from nucleolar breakdown. On the other hand, in practically all of the 46 diakinesis and metaphase $I$, and in 21 of the anaphase and telophase I cells of strain Valls 1753 investigated, structures like those named as nuclear bodies by Walters (1963, 1965, 1966 and 1968) were seen (Fig. 5). They may be the product of the synthetic activity of the chromosomes during certain stages of the division.

Table 3 presents the data on anaphase and telophase I chromosome distribution.

Table 7. Ecologic and morphologic characteristics

\begin{tabular}{|c|c|c|c|c|c|}
\hline Characteristics & $\begin{array}{l}\text { A. flabelli- } \\
\text { formis var. } \\
\text { camporum }\end{array}$ & $\mathrm{C}$ & D & $\mathbf{H}$ & $F$ \\
\hline \multicolumn{6}{|l|}{ Ecologic } \\
\hline $\begin{array}{l}\text { Type of } \\
\text { environment }\end{array}$ & $\begin{array}{l}\text { Dry soil, } \\
\text { between } \\
\text { shrubs and } \\
\text { tall grasses }\end{array}$ & $\begin{array}{l}\text { Dry to } \\
\text { intermediate } \\
\text { soil, open } \\
\text { field }\end{array}$ & $\begin{array}{l}\text { Dry to } \\
\text { intermediate } \\
\text { soil, fields } \\
\text { slightly humid }\end{array}$ & $\begin{array}{l}\text { Dry to } \\
\text { intermediate } \\
\text { soil, open } \\
\text { field }\end{array}$ & $\begin{array}{l}\text { Dry to } \\
\text { intermediate } \\
\text { soil, open } \\
\text { field }\end{array}$ \\
\hline \multicolumn{6}{|l|}{ Morphologic } \\
\hline Habit & Cespitose & Cespitose & Cespitose & Cespitose & Stoloniferous \\
\hline Plant's height & High & Low & High & High & High \\
\hline Innovations & Intravaginate & Intravaginate & Intravaginate & Intravaginate & Intravaginate \\
\hline \multicolumn{6}{|l|}{ Leaf blade } \\
\hline - length/width & $\begin{array}{l}\text { Semi-long/ } \\
\text { narrow }\end{array}$ & Long/wide & $\begin{array}{l}\text { Short/ } \\
\text { narrow }\end{array}$ & $\begin{array}{l}\text { Long/ } \\
\text { narrow }\end{array}$ & $\begin{array}{l}\text { Long/ } \\
\text { narrow }\end{array}$ \\
\hline - form & Linear-obtuse & Linear-obtuse & Linear-obtuse & Linear-obtuse & Linear-obtuse \\
\hline - color & Light green & Yellow green & Green & Yellow green & Green \\
\hline Prefoliation & Conduplicate & Conduplicate & Conduplicate & Conduplicate & Conduplicate \\
\hline \multicolumn{6}{|l|}{ Inflorescence } \\
\hline raceme color & Purple & Brown purple & Purple & Brown & Brown \\
\hline $\begin{array}{l}\text { raceme posi- } \\
\text { tion }\end{array}$ & Erect & Erect & Erect & Divergent & Erect \\
\hline raceme number & $10-20$ & $(5)-12$ & $17-19$ & $9-17$ & $5-10$ \\
\hline anther color & Purple & Purple & Purple & Purple & Purple \\
\hline $\begin{array}{l}\text { spikelet length } \\
(\mathrm{mm})\end{array}$ & $1.6-1.8$ & $2.0-2.2$ & $2.0-2.2$ & $2.0-2.2$ & $2.2-2.4$ \\
\hline $\begin{array}{l}\text { spikelet } \\
\text { pilosity }\end{array}$ & $\begin{array}{l}\text { Hairs between } \\
\text { the nervures }\end{array}$ & Pilous rachis & Glabrous & Pubescent & Glabrous \\
\hline $\begin{array}{l}\text { Long hairs on } \\
\text { the pedicels }\end{array}$ & Present & Present & Present & Present & Present \\
\hline $\begin{array}{l}\text { Axillary } \\
\text { inflorescences }\end{array}$ & 1 & 1 & 1 & 1 & 1 \\
\hline
\end{tabular}

The numbers in parentheses indicate values that occur only rarely.

About four fifths of the 577 cells studied showed a regular picture. The number of laggards in the irregular ones agreed, in a general way, with the number of univalents seen at metaphase $\mathrm{I}$.

The results concerning the pollen stainability are shown in Table 4. There again exists a favorable agreement with the observations of meiotic pairing and segregation, this being especially true for the entities of the Axonopus series, the 
tetraploids of the Suffulti and $A$. cf. siccus of the Barbigeri series. On the other hand, in the Suffulti diploid forms and in $A$. cf. malmei the low frequency of apparently normal pollen was unexpected, due to the regular pairing and segregation observed. This may occur because of some kind of undetected chromosome or gene sterility, but environmental factors might also be involved.

Tables 5, 6 and 7 present the ecologic and morphologic characteristics of the of the entities from the Suffulti series

\begin{tabular}{|c|c|c|c|c|c|}
\hline G & $\mathrm{E}$ & I & A & B & A. ramboi \\
\hline $\begin{array}{l}\text { Dry to inter- } \\
\text { mediate soil, } \\
\text { open field }\end{array}$ & $\begin{array}{l}\text { Dry to inter- } \\
\text { mediate soil, } \\
\text { open field }\end{array}$ & $\begin{array}{l}\text { Dry to inter- } \\
\text { mediate soil, } \\
\text { open field }\end{array}$ & $\begin{array}{l}\text { Dry to inter- } \\
\text { mediate soil, } \\
\text { open field }\end{array}$ & $\begin{array}{l}\text { Dry to inter- } \\
\text { mediate soil, } \\
\text { open field }\end{array}$ & $\begin{array}{l}\text { Humid, foggy } \\
\text { areas }\end{array}$ \\
\hline Stoloniferous & Cespitose & Cespitose & Cespitose & Cespitose & Rhizomatous \\
\hline High & High & High & Low & Low & Low \\
\hline Extravaginate & $\begin{array}{l}\text { Intra and } \\
\text { extravaginate }\end{array}$ & Intravaginate & Extravaginate & Extravaginate & Extravaginate \\
\hline $\begin{array}{l}\text { Intermediate/ } \\
\text { wide }\end{array}$ & Long/wide & Long/wide & Short/wide & Short/wide & $\begin{array}{l}\text { Long/ } \\
\text { narrow }\end{array}$ \\
\hline Linear-obtuse & Linear-obtuse & Linear-obtuse & Linear-obtuse & Linear-obtuse & Linear-obtuse \\
\hline Yellow green & Yellow & Dark green & Yellow green & Yellow green & Yellow green \\
\hline Conduplicate & Conduplicate & Conduplicate & Conduplicate & Conduplicate & Conduplicate \\
\hline Brown & Brown & Purple & Brown & Purple & Purple \\
\hline Divergent & Erect & Divergent & $\begin{array}{l}\text { Strongly } \\
\text { divergent }\end{array}$ & Divergent & Ascendant \\
\hline $9-12$ & $16-18$ & $14-16$ & (4) $-10-14$ & $7-13$ & $15-20$ \\
\hline Purple & Purple & Purple & Purple & Purple & Purple \\
\hline $2.2-2.4$ & $2.4-2.5$ & $2.2-2.4$ & $2.1-2.3$ & $2.4-2.7$ & $2.7-2.9$ \\
\hline $\begin{array}{l}\text { Glabrous and } \\
\text { some with } \\
\text { hairs along } \\
\text { the rachis }\end{array}$ & Glabrous & $\begin{array}{l}\text { Glabrous, } \\
\text { sparsely } \\
\text { pilous rachis }\end{array}$ & $\begin{array}{l}\text { Glabrous, } \\
\text { some pilous; } \\
\text { pilous rachis }\end{array}$ & $\begin{array}{l}\text { Pilous; } \\
\text { pilous } \\
\text { rachis }\end{array}$ & Glabrous \\
\hline Present & Present & Present & Present & Present & Present \\
\hline 1 & 1 & 1 & 1 & 1 & 1 \\
\hline
\end{tabular}

taxa considered in the Axonopus and Suffulti series. Since only five strains belonging to two species were studied in the Barbigeri one, they were not included in this analysis. The traits considered were not the same in the two series because some of them differ in their importance for the taxonomic discrimination of the forms. 


\section{Discussion}

The arrangement in Table 5 of the tetraploid forms is such that it indicates the decreasing degree of morphologic and ecologic similarity between them and the diploid $A$. purpusii var. purpusii. If we establish as AA the genomic formula for the latter, $A$. purpusii var. glabrescens would be $\mathrm{AAB}_{1} \mathrm{~B}_{1}$ and $A$. fissifolius var. fissifolius $\mathrm{AAB}_{2} \mathrm{~B}_{2}$. A. parodii is similar to $A$. purpusii var. glabrescens and could be classified as $\mathrm{B}_{1} \mathrm{~B}_{1} \mathrm{DD}$. On the other hand, since there is a general likeness between $A$. fissifolius var. fissifolius and $A$. affinis, the latter could be represented as $\mathrm{AAA}_{1} \mathrm{~A}_{1}$ $\mathrm{B}_{2} \mathrm{~B}_{2} \mathrm{~B}_{3} \mathrm{~B}_{3}$. The hybrid $A$. $\times$ riograndensis is very similar to $A$. affinis, but presents some characteristics which are typical of the Suffulti series; its formula could be $\mathrm{AA}_{1} \mathrm{~A}_{2} \mathrm{~A}_{3}$ $B_{2} B_{3}$ if we postulate that an unknown form of this series $\left(A_{2} A_{2} A_{3} A_{3}\right)$ has also participated in its formation. If this hypothesis is true, the absence of multiple associations in A. affinis could have been due to some sort of genotypic control.

As for the entities of the Axonopus series, group near A. compressus var. compressus (Table 6), no formula could be established for $A$. $\times$ repens, since its ploidy level was not determined with certainty; $A$. jesuiticus would be $\mathrm{CCD}_{1} \mathrm{D}_{1}$, while the hybrid $A$. $\times$ rosengurttii, which shows some likeness with the former, would be classified as $\mathrm{CCD}_{1} \mathrm{D}_{1} \mathrm{~F}_{2} \mathrm{G}_{1}$. The hexaploid $A$. compressus var. compressus could be represented as EEFFGG and $A$. polystachyus as $F_{1} F_{1} G_{1} G_{1} H H$. The former has probably contributed to the formation of $A . \times$ araujoi $\left(\mathrm{EE}_{1} \mathrm{FF}_{1} \mathrm{G}\right)$, A. obtusifolius var. obtusifolius (EEFFGGHHII) and $A . \times$ compressoides, which probably also received a genome from $A$. affinis, its formula therefore being $\mathrm{AA}_{1} \mathrm{~B}_{2} \mathrm{~B}_{3} \mathrm{EFG}$. The hybrid $A$. $\times$ rolfsii, which is similar to $A$. obtusifolius var. obtusifolius, can be characterized as $\mathrm{EE}_{2} \mathrm{FF}_{2} \mathrm{GHIJ}$.

The forms of the Suffulti series (Table 7) show much more similarities among themselves than those discussed previously. The diploids could be described as follows: $\quad \mathrm{C}: \mathrm{A}_{2} \mathrm{~A}_{2} ; \mathrm{H}: \mathrm{A}_{3} \mathrm{~A}_{3} ; \mathrm{D}: \mathrm{A}_{5} \mathrm{~A}_{5}$; and A. flabelliformis var. camporum: $\mathrm{A}_{7} \mathrm{~A}_{7}$. The tetraploids, with the exception of $A$. ramboi, show a large amount of similarities with $C, H$ and $D ; A, B$, and $I$ could be characterized by the same formula $\left(A_{2} A_{2} A_{3} A_{3}\right)$, while $E$ and $F$, with a large degree of likeness would both be $A_{3} A_{3} A_{5} A_{5}$. The genomic formula of $G$ could be $A_{3} A_{3} A_{0} A_{0}$ and the one of $A$. ramboi $A_{4} A_{4} B_{0} B_{0}$.

Chromosome numbers from the following species studied here had already been determined by other authors at the time of our investigation: A. purpusii (Reeder 1966, Pohl and Davidse 1971); A. jesuiticus (Markus 1960); A. compressus (JanakiAmmal 1945, Delay 1950, Nuñes 1952, Gledhill 1962, 1966, Davidse and Pohl 1972) and A. affinis (Burton 1942, Brown 1948, Gledhill 1962, Gould and Soderstrom 1967, 1970, Gould 1968, Davidse and Pohl 1972). As for the Suffulti series, only two other studies have been located by us reporting cytogenetic findings: Nuñes (1952) investigated $A$. iridaceus and de Wet and Anderson (1956) A. suffultus. In a general way our results agree with those reported by these authors. But in relation to A. compressus Delay (1950) and Davidse and Pohl (1972) described penta, octo and decaploid forms, while we encountered tetra and hexaploid entities only; whereas for $A$. affinis there are counts of $2 n=20$ by Gould and Soderstrom (1967) and also $2 n=40$ by Gould (1968) and Davidse and Pohl (1972), our findings of 
$\mathrm{n}=40$ being however in accordance with the data observed in most investigations.

If we compare the results obtained in the two series for which we have gathered sufficient information, Axonopus and Suffulti, it is possible to suppose that the first, which presents all the levels observed in the genus, is the oldest; while within it, the group near $A$. compressus, showing the highest chromosome numbers, would have attained the most advanced level of maturity. On the other hand, the typically amphidiploid behavior observed in several entities of the two Axonopus groups suggests that the interspecific hybridization should have had an important role in the formation of these taxa.

The occurrence of natural hybrids involving as probable parents entities of the two groups $(A . \times$ compressoides $)$ and even of the two series $(A . \times$ riograndensis $)$ indicates that the forms of the genus Axonopus can establish evolutionary networks which combine genes from divergent lines, as in Bromus and other genera (Stebbins 1956). On the other hand, the low frequencies of multiple associations observed among the tetraploids of the Suffulti series could be explained in two ways: a) low homeology of the genomes involved in their origin; or b) they would have originated by polyploidization of intraspecific hybrids, with selection favoring the establishment of a regular meiotic process. The morphologic and ecologic similarities observed in the three diploids which are probably involved in their origin and the absence of a clear cytologic distinction among the latter give support to the second hypothesis. We could therefore consider all the forms as different subspecies of a single polymorphic species, as was already observed for example in Dactylis ((Zohary 1955, Stebbins 1956) and in the Notata group of the genus Paspalum (Moraes Fernandes et al. 1973).

\section{Summary}

Chromosome number, meiotic behavior, pollen stainability and other morphologic and ecologic data from 35 strains belonging to 29 natural and cultivated entities of the genus Axonopus collected in Rio Grande do Sul, other Brazilian States and Uruguay are reported. In the series Axonopus $n$ varied from 10 to $50(2 \mathrm{x}-10 \mathrm{x})$; the series Suffulti shows diploid and tetraploid entities, while in Barbigeri only diploids were observed. In a general way our results agree with those obtained by other authors in those taxa where previous cytological studies were made; some ploidy levels observed in $A$. compressus and $A$. affinis, however, were not encountered by us. Meiotic abnormalities were most frequent in the Suffulti series, occurring in six of the seven tetraploid entities studied; in the Axonopus series about half of the polyploid forms had a regular meiotic behavior, while the five Barbigeri strains studied showed an essentially regular pattern. Subspecific hybridization may be involved in the origin of the taxa of the first series, while in the second allopolyploidy may have played an important role. Peculiar non-chromosomic structures were observed in the pollen mother cells of two strains of the series Suffulti, resembling the round and nuclear bodies described previously in Zea and Bromus. 


\section{Acknowledgments}

We thank Neiva Simões and G. V. Simões for help in the field and in the laboratory, as well as A. Pott, L. Arzivenco and E. Kornelius for furnishing some of the material studied here. Our work is supported by the Câmara Especial de Pósgraduação e Pesquisa da Universidade Federal do Grande do Sul, Conselho Nacional de Pesquisas, Coordenação do Aperfeiçoamento de Pessoal de Nível Superior, and Fundação de Amparo à Pesquisa do Estado do Rio Grande do Sul.

\section{References}

Black, C. A. 1963. Grasses of the genus Axonopus. Adv. Front. Pl. Sci. 5: 1-186.

Brown, W. V. 1948. A cytological study in the gramineae. Am. J. Bot. 37: 382-395.

- 1950. A cytological study of some Texas grasses. Bull. Torrey Bot. Club 77: 63-76.

Burton, G. W. 1942. Cytological study of some species in the tribe Paniceae. Am. J. Bot. 29: 355-359.

Davidse, G. and Pohl, R. W. 1972. Chromosome numbers and notes on some Central American grasses. Can. J. Bot. 50: 273-283.

Delay, C. 1950. Nombres chromosomiques chez les Phanérogames. Rev. Cytol. Biol. Véget. 12: $1-368$.

De Wet, J. M. J. and Anderson, L. J. 1956. Chromosome numbers in Transvaal grasses. Cytologia 21: $1-10$.

Gledhill, D. 1962. Biosystematic studies of the Axonopus compressus complex; a new subspecies from West Africa. Phytomorphology 12: $412-418$.

- 1966. Cytotaxonomic revision of the Axonopus compressus (Sw) Beauv. complex. Bol. Soc. Broteriana 40: $125-147$.

Gould, F. W. 1968. Chromosome numbers of Texas grasses. Can. J. Bot. 46: 1315-1325.

- and Soderstrom, T. R. 1967. Chromosome numbers of tropical American grasses. Am. J. Bot. 54: 676-683.

- 1970. Chromosome numbers of some Mexican and Colombian grasses. Can J. Bot. 48: 16331639.

Janaki-Ammal, E. K. 1945. In: Darlington, C. D. and Janaki-Ammal, E. K. Chromosome Atlas of Cultivated Plants. Allen and Unwin, London.

Markus, R. 1960. Melhoramento das plantas forrageiras. An. Assoc. Gabriel. Melhor. Renov. Past. (S. Gabriel, RS): 61-75.

Moraes Fernandes, M. I. B. de, Barreto, I. L. and Salzano, F. M. 1973. Cytogenetic, ecologic and morphologic studies in Brazilian forms of Paspalum notatum. Can J. Genet. Cytol. 15: 523-531.

Newcomer, E. H. 1953. A new cytological and histological fixing fluid. Science 118: 161.

Nuñes, O. 1952. Investigaciones cariosistemáticas en las gramineas argentinas de la tribu Paniceae. Rev. Fac. Agron. La Plata 28 : 229-255.

Parodi, L. R. 1938. Gramineas austroamericanas nuevas o críticas. Notas Mus. La Plata 3: 13-33.

Pohl, R. W. and Davidse, G. 1971. Chromosome numbers of Costa Rican grasses. Brittonia 23: 293-324.

Reeder, J. R. 1966. In: Löve, A. IOPB chromosome number reports VI. Taxon 15: 117.

Rosengurtt, B., Arrilaga de Maffei, B, and Izaguirre de Artucio, P. 1970. Gramineas Uruguayas. Univ. de la Republica, Montevideo.

Stebbins, G. L. 1956. Cytogenetics and evolution in the grass family. Am. J. Bot. 43: 890-905.

Walters, M. S. 1963. A nuclear body in meiosis of Bromus. Chromosoma 14: 347-359.

-1965. A nuclear body in microsporocytes of Zea mays. Chromosoma 17: 78-84.

- 1966. Non-chromosomal entities in mitosis and meiosis of Bromus arizonicus. Heredity 21: $537-545$.

- 1968. Ribonucleoprotein structures in meiotic prophase of Zea mays. Heredity $23: 39-47$.

Zohary, D. 1955. Cytogenetic Studies in the Polyploid Complex of Dactylis glomerata. M. S. Thesis, Univ. of California. 